\title{
The cross-over effect of irrational sentiments in housing, commercial property, and stock markets
}

\author{
Prashant Das ${ }^{a, b, *}$, Roland Füss ${ }^{c, d, e}$, Benjamin Hanle ${ }^{c}$, Isabel Nina Russ ${ }^{c}$ \\ a Indian Institute of Management, Ahmedabad, India \\ ${ }^{\mathrm{b}}$ EHL Lausanne-HES.SO//University of Applied Sciences and Arts Western Switzerland \\ c Swiss Institute of Banking and Finance (s/bf), University of St.Gallen, Unterer Graben 21, 9000 St. Gallen, Switzerland \\ ${ }^{\mathrm{d}}$ Centre for European Economic Research (ZEW), Mannheim, Germany \\ e Center for Real Estate and Environmental Economics, NTNU Business School, Trondheim, Norway
}

\section{A R T I C L E I N F O}

\section{Article history:}

Received 31 May 2018

Accepted 28 February 2020

Available online 2 March 2020

\section{JEL classification:}

C32

C53

G40

R30

\section{Keywords:}

Commercial real estate

Housing market

Investor sentiment

Predictability

Stock market

\begin{abstract}
A B S T R A C T
This paper examines the dependence in irrational sentiments across housing, commercial property, and stock markets. Our empirical results document an important and lasting impact that commercial real estate sentiment and returns have on broader financial markets. We also show that the cross-over effects of market sentiments are not consistent with cross-over effects in market returns. Sentiments and returns in housing and stock markets exhibit strong dependence on other markets, whereas they evolve independently in commercial real estate. While housing and stock market returns respond to irrational sentiment in commercial real estate markets, the opposite is not true.
\end{abstract}

(C) 2020 Elsevier B.V. All rights reserved.

\section{Introduction}

Recent literature affirms that investor sentiment, beyond fundamentals, plays an important role in asset pricing, and more particularly, in real estate markets. Investor sentiment is defined as "a belief about future cash flows and investment risks that is not justified by the facts at hand" (Baker and Wurgler, 2007). In inefficient private markets such as the real estate market the role of sentiment is manifold. Because real estate is both a consumption and investment good, factors other than rational considerations might affect its valuation. In housing markets for example, the emotional response of potential homebuyers weighs heavily on transactions. In contrast, one can naturally assume that participants in markets for income-producing properties behave more rationally. However, in these more efficient commercial real estate (CRE) markets the specific market microstructure, the heterogene-

\footnotetext{
* Corresponding author.

E-mail addresses: prashant.pkd@gmail.com (P. Das), roland.fuess@unisg.ch (R. Füss), b.hanle@hanle.de (B. Hanle), isabel.russ@russmedia.com (I.N. Russ).
}

ity of properties, and the existence of proprietary information on individual assets and local markets makes asset pricing prone to sentiment in terms of mood, greed, or fear. Even in highly efficient markets such as the stock market, sentiment has proven to be a priced risk factor (see, e.g., Brown and Cliff, 2005; Da et al., 2015).

Within the residential sector, Ionnides and Rosenthal (1994) show that compared to consumption demand, the investment demand for housing is more sensitive to wealth and income. However, the demand for residential and commercial real estate (CRE) is directly exposed to common macroeconomic factors (Ling and Naranjo, 1999; Hoesli and Reka, 2015; Duca and Ling, 2020). CRE markets, beyond the residential sector, have a significant impact on the business cycle (Quigley, 1999), a phenomenon that is widely ignored in the literature (Levitin and Wachter, 2013).

During property market booms, investors switch capital from other asset classes to CRE (Das et al., 2015). Moreover, the increasing volume of property loans and their securitization have led to severe financial market cycles internationally (Ball et al., 2002). Yet, the channels through which residential and commercial real estate, as well as financial markets affect each other, are 
not well documented. In this study, we reconcile earlier findings on each of these markets, which previously were mostly studied in isolation, and enhance the body of knowledge by examining correlations and spillovers among asset markets in sentiments and returns as well as in their cross-over from one market to another.

In general, irrational investor sentiment in real estate markets and its impact on the pricing of properties is difficult to quantify. First, a highly segmented real estate market, which encompasses different sectors and various market participants, leads to multiple, unique measures of investor sentiment. Second, the measurement of sentiment is by nature not straightforward, because of its association with economic fundamentals. Third and more importantly, the lack of timely information on private markets forces investors to draw inferences about price movements in one segment (e.g., residential or commercial) from another or from public equity market counterparts (e.g., real estate investment trusts (REITs)).

We address the above-mentioned issues by examining a system of variables comprising housing, commercial real estate and equity, as well as a broad range of corresponding proxies for investor sentiments. We focus on developing unique sentiment measures for individual real estate market segments, which are not explained by, and therefore disentangled from, relevant macroeconomic fundamentals. The aim is to draw a relationship between asset returns and different types of sentiment, and more importantly, to estimate the extent of their dynamics and interdependence. Further, we analyze the role of various sentiments for real estate returns in order to evaluate their relative importance and forecasting ability. To our knowledge, this is the first study to analyze the interdependence of sentiments among residential and commercial real estate sectors, as well as the stock market, i.e. between private and public markets.

Our empirical models highlight the intertwined and asymmetric dynamics in returns and sentiments across the three markets. Housing sentiment is positively affected by stock market sentiment and negatively by irrational pessimism in commercial real estate markets. On the other hand, while residential real estate sentiment significantly affects stock market sentiment, commercial real estate sentiment evolves almost independent of the sentiments in the other two markets. Yet, we observe a significant cross-over effect between sentiments and returns among the housing and commercial markets. Residential returns are inflated by sentiments in the commercial markets. Commercial property returns, although inefficient, are unaffected by irrational sentiments in any of the three markets. In general, we detect an irrational divide across sentiment and return perception. While the returns across various markets are endogenously interrelated, the corresponding sentiments do not echo these interrelations.

The remainder of the paper is structured as follows: Section 2 reviews the related literature along a simple theoretical framework in order to illustrate how sentiment affects asset returns. The section elaborates on our hypotheses on the spillover and cross-over effects of market sentiments. Section 3 introduces the different types of sentiment indices and our estimation strategy. Section 4 presents the data and Section 5 discusses our main findings. Section 6 concludes.

\section{Household and investor sentiment in asset markets}

This section provides a review of the relevant literature along a theoretical framework about how sentiment affects asset returns in general and real estate markets in particular. It further develops hypotheses on the cross-over effects of sentiments among housing, commercial property, and stock markets.

\subsection{Theoretical background}

Baker and Wurgler (2007) characterize investor sentiment as "a belief about future cash flows and investment risks that is not justified by the facts at hand." Thereby, sentiment includes purely psychological ("irrational" hereafter) aspects of decision making, which are not explained by fundamental information. Black (1986) and Shefrin and Stateman (1994) introduce two types of investors, the information trader acting only on perfect information and the noise trader acting partly on imperfect information. In markets with significant limits-to-arbitrage such as the real estate market, it is assumed that noise trading can create persistent arbitrage opportunities (Ling et al., 2014; Das et al., 2017) by influencing asset returns and volatility. ${ }^{1}$ To quantify this noise trading risk, various sentiment measures were introduced to directly or indirectly capture the irrational component of investors.

Direct measures of sentiments such as the University of Michigan Consumer Sentiment Index, the survey by the American Association of Individual Investors (AAII), and SITUS/Real Estate Research Corporation (RERC) investor survey are constructed via surveys on opinions, beliefs, and perceptions of investors (Clarke and Statman, 1998; Fisher and Statman, 2000; Brown and Cliff, 2004). Indirect measures of investor sentiment are related to a variety of financial indicators such as the closed-end fund discount, share turnover, the dividend premium, the number of IPOs and their first-day returns, or the contemporaneous and lagged equity share in new issues (Lee et al., 1991; Neal and Wheatley, 1998; Lowry, 2003; Baker and Wurgler, 2006, 2007; Ling et al., 2014). Composite sentiment indices derived from the first principal component (PCA) of several sentiment proxies are able to combine both rational and irrational components of sentiments. Before developing the PCA measures in order to single out the irrational aspect of investor sentiment, the sentiment variables are regressed on a set of control variables depicting major macroeconomic influences (Brown and Cliff, 2004, 2005; Baker and Wurgler, 2006, 2007). The resulting 'pure' sentiment index is then independent of business cycle variation and only captures the part of investors' expectations and beliefs that is not grounded on fundamental factors.

In our empirical analysis, we are mainly interested in how the level of sentiment, i.e. optimism, neutrality, and pessimism, in one market affects the level of sentiments and returns in other capital markets. Unlike some earlier studies such as Ling et al. (2014), which focus on changes in the first difference of sentiment, we measure the effect of a change in the level of sentiment. Focusing on the level of sentiments allows us to cleanly differentiate between different 'states' of sentiment among the markets. Our approach is in line with Das et al. (2015) and Freybote and Seagraves (2018).

To provide a theoretical framework for sentiment and return cross-over effects, we firstly follow Shefrin (2008) and introduce a sentiment measure $\Phi$ to the stochastic discount factor (SDF) representation:

$\Phi\left(x_{t}\right)=\frac{P_{R}\left(x_{t}\right)}{\Pi\left(x_{t}\right)}$,

where $P_{R}\left(x_{t}\right)$ is the subjective probability assigned by the noise trader to the date-event pair $x_{t}$ and $\Pi$ is the rational or objective belief. We further define the log of sentiment:

$\ln (\Phi)=\Lambda \equiv \ln \left(\frac{P_{R}}{\Pi}\right)$

\footnotetext{
1 The real estate market experiences various market imperfections such as liquidity constraints, market entry barriers, indivisible assets, high transaction costs, lack of transparency, heterogeneous assets, and information asymmetry. Empirical tests of the efficiency include Hamilton and Schwab (1985) or Case and Shiller (1988) for residential real estate and Gau (1987), McIntosh and Henderson (1989), and Evans (1990) for the commercial real estate market.
} 
In addition, we assume that with increasing weight of noise traders in the composition of the representative agent, the implied level of sentiment and risk aversion in the market will change because of averaged consumption patterns and beliefs. We therefore extend the argument made by Campbell et al. (1993), which states that the level of risk aversion for individual agents is exogenous, but for the market maker it depends on the composition of individual agents. We define the SDF for the individual agent $m_{j}$ as the sum of sentiment and the consumption growth rate $g$, resulting in the SDF for the representative investor $m^{*}$ :

$$
\begin{aligned}
& m_{j}= \begin{cases}\Lambda-\gamma_{R} \ln (g), & j=\text { Noise Trader } \\
\gamma_{R} \ln (g), & j=\text { Information Trader }\end{cases} \\
& m^{*}=\lambda_{t} m_{\text {Noise }}+\left(1-\lambda_{t}\right) m_{\text {Information }}
\end{aligned}
$$

where $\lambda_{t}$ defines the weight of the noise trader and $\gamma_{R}$ the level of relative risk aversion. Eq. (3) states that the SDF of the representative investor $m^{*}$ is the result of both a sentiment and a fundamental component. Here, the modified SDF function incorporates sentiment of all affected markets, in turn influencing the pricing of all markets depending on the respective weights of noise traders and levels of risk aversion. Hence, sentiment cross-over effects should be considered an integral part of the pricing process.

Shefrin (2008) further argues that given a sentiment component in the SDF, the risk premium for any asset does not only depend on the covariance between SDF and asset returns (fundamental premium), but also on a sentiment premium. Such formalization makes it possible to move from the CAPM realm to the Behavioral CAPM (BAPM) presented by Shefrin and Statman (1994), Brown and Cliff (2005), Da et al. (2015) and Füss et al. (2019) in which returns are subject to an explicit sentiment index. ${ }^{2}$ In line with earlier findings that associate sentiments with returns, we hypothesize.

Hypothesis 1. Sentiments in housing, commercial real estate, and stock markets are priced risk factors and consequently affect returns in their corresponding markets.

Hypothesis 1 focuses on the effect in each respective market. However, in this study, we are particularly interested in the spillovers of sentiments and the cross-over between sentiments and returns among housing, CRE, and stock markets. These assets share a complex relationship, which trigger such spillover and cross-over effects in sentiment among markets.

\subsection{Market structure and investor behavior}

The three markets differ in their market microstructure. Private markets for housing and commercial properties are OTC markets, on which transactions are privately negotiated. These markets are characterized by low transparency, low liquidity, limited arbitrage opportunities, and infrequent trading. They are therefore less informationally efficient, which makes them more prone to sentimentdriven prices. In contrast, in public markets, such as the stock market, information is instantaneously incorporated into prices. Due to its high degree of information efficiency, it is natural to assume that the stock market leads the other markets (Fama, 1991; Malkiel and Fama, 1970). ${ }^{3}$

Sentiment is an investor-driven rather than an asset-related risk factor. Investments in residential real estate are dominated by individuals and households, while institutional investors are primarily

\footnotetext{
2 Ramiah and Davidson (2007) estimate the behavioral beta empirically and conclude that only $37 \%$ of all transactions can be explained with the traditional market beta.

3 This is also confirmed by our data in Table 3, where we document positive autocorrelation in returns with the highest autoregressive coefficients for residential, followed by CRE, and lowest and insignificant for stock markets.
}

active in commercial real estate markets (Lizeri, Baum and Scott, 2000). ${ }^{4}$ After the global financial crisis of 2007-2008, some anec$\operatorname{dotal}^{5}$ as well as academic evidence (Immergluck and Law, 2014; Chilton et al., 2018; Charles, 2019) emerged suggesting an increased role of institutional investors (REITs, hedge funds, private equity funds etc.) in single-family home markets. However, institutional acquisition of single-family homes still represents less than two percent of such transactions. ${ }^{6}$ More importantly, these acquisitions are made with the purpose of converting, mainly distressed, single-family homes into single-family rental (SFR) units. As SFR, such owner-occupied homes are converted into commercial real estate managed by institutional investors whose behavior is captured by sentiment in the commercial real estate market for rental property units.

In terms of the quality of information acquisition, the housing market has a significant proportion of noise traders, which act onat least in part-imperfect information. According to a 2016 survey conducted by the National Association of Realtors, ${ }^{7}$ one third of home buyers are first-time buyers. The remaining two third are already experienced in making the most significant investment of their life. Although the average tenure in the home is reported as 10 years, housing remains a consumption good and the role of irrationality in such investments cannot be obviated. However, we should expect that a second-time homebuyer will behave more rationally. Therefore, our empirical models reflect a rather conservative view on the significant role of sentiments in home purchases. On commercial property markets, information traders act on perfect information, but they are confronted with a certain market microstructure that delays the pricing process. In contrast, stock markets attract both institutional investors (information traders) and individual investors (noise traders) (Nofsinger and Sias, 1999).

Households generate income from labor and their wealth in assets such as stocks, bonds, or real estate in terms of dividends, rents and value appreciation (Vissing-Jørgensen and Attanasio, 2003). Hence, if housing and stock markets are doing well, households consume more, which affects the economy and in turn commercial real estate. Households also increase their investments in housing when stocks and bonds contribute to a rise in their wealth portfolio (Leamer, 2015). Further, Lai and Order (2017) emphasize the fundamentally driven mean-reverting properties of the residential market, i.e. the deviation from their fundamental value in the short run. In addition, households' property values are also affected by investments of institutional investors in multi-family homes in the local neighborhood.

Commercial real estate and stock markets are directly related through the business cycle. Stock prices increase when business is expected to improve. An improved economy triggers higher occupancy rates, rents, and prices in industrial, retail, and office sectors (Sivitanidou and Sivitanides, 1999). Finally, the economic boom is felt in residential markets via increasing housing wealth. Likewise, the interest rate is simultaneously associated with housing, CRE, and stock markets. While lower discount rates or yields lead to higher prices at investment markets, lower financing costs makes housing more affordable.

Both households and institutional investors allocate shares of their wealth and funds to the stock market. However, the over-

\footnotetext{
${ }^{4}$ Note that our performance measure for CRE (i.e., NCREIF Property Index) is predominantly reflective of institutionally owned assets.

5 See, for example: https://www.theatlantic.com/technology/archive/2019/02/ single-family-landlords-wall-street/582394/.

${ }^{6}$ See https://www.forbes.com/sites/forbesrealestatecouncil/2019/11/01/where-isthe-new-class-of-investors-buying-single-family-rentals/\#4c926c846c0f. Also, our sample period ranges from 1997 to 2015 including fewer years when institutional investors were more actively trading in the single-family housing market.

7 https://www.nar.realtor/sites/default/files/reports/2016/2016-profile-of-homebuyers-and-sellers-10-31-2016.pdf.
} 
lap of homes and CRE asset holdings among institutional investors is rare. Institutional investors, who invest in CRE and stock markets, are subject to scrutiny by their shareholders. They monitor individual investment behavior (Grinblatt and Keloharji, 2000) and tend to be better informed (Li et al., 2017). Besides, institutional investors are known to switch capital across markets (Das et al., 2015). Therefore, it seems likely that spillovers in sentiments and a cross-over of sentiments and returns between CRE and stock markets take place. However, unlike stock markets, which include both retail and institutional investors, the CRE markets are dominated by sophisticated institutional investors. In contrast, individual ("retail") investor decisions rely heavily on the opinion of experts (Levitt and Syverson, 2008). According to our model and suggested in the past literature, institutional investors are perceived to be more sophisticated. These informed investors will be less affected by household sentiment, while households are considered to be predominantly noise traders.

\subsection{Spillovers in sentiments}

Spillovers in sentiment always occur when sentiment in one market influences sentiments in other markets. While sentiment and returns within a market determine each other (Brown and Cliff, 2005; Da et al., 2015) and returns across asset markets are increasingly correlated due to global common factors (see, e.g., Vissing-Jørgensen and Attanasio, 2003; Sivitanidou and Sivitanides, 1999), one can also expect co-movements and spillovers in sentiments across markets. However, spillovers of sentiments across markets do not need to be symmetric given the varying level of investor sophistication across investor types in processing new information (Li et al., 2017).

Except some studies wherein both institutional investors and individuals are shown to be prone to biases in investment decision making (Bokhari and Geltner, 2011), a relatively larger body of literature tends to portray individual and institutional investors at differing levels of sophistication. Individual investors are reported to behave more irrationally than institutional investors (Goodfellow et al., 2009; Kumar and Lee, 2006; Schmeling, 2007). Housing, as consumption and investment goods of households (who are less sophisticated), is more prone to sentiment-driven, "noisy" investment behavior. In contrast, the CRE market is dominated by institutional investors, and thus, is expected to have superior information processing capability (Lizeri, Baum, and Scott, 2000). Even though the stock market accommodates both types of investors, a significant market share is owned by institutional investors (Nofsinger and Sias, 1999), i.e. it should exhibit superior sophistication compared to housing. While institutional investors dominate in less efficient CRE markets and both informed and noise traders are active in highly efficient stock markets, the difference in their sensitivity to sentiment between the two markets remains an empirical question.

In particular, we should expect that residential sentiments are reinforced by sentiments in CRE and stock markets. Given the role of the housing sector in the overall economy as "the single most critical part of the U.S. business cycle" (Leamer, 2015), and the perceived noise trading by households, who dominate the residential sector, sophisticated investors may take a cautious view to housing market sentiment. In the same vein, CRE sentiment should take a contrarian view to residential sentiments, but be reinforced by stock market sentiments. Taking a contrarian view to residential sentiments by itself is not an irrational behavior as long as individuals are considered to be noise traders and such a contrarian view nullifies an investor's own irrational sentiment in asset pricing. Due to an overlapping pool of institutional investors, sentiments in CRE and stock markets are influenced by each other. Accordingly, we develop our second hypothesis.
Hypothesis 2. Residential sentiment is influenced by sentiments in CRE and stock markets with the latter two reinforcing each other, but taking a contrarian view to housing market sentiment.

\subsection{Cross-over in sentiments and returns}

We define the cross-over in sentiments and returns as spillovers from sentiment in one market to returns in other markets. Several studies document sentiment-driven investment behavior by private and institutional investors. However, unlike individual sentiment, which has little predictive power, institutional sentiment is known to impact asset prices (Lilian and Wu, 2007; Nofsinger and Sias, 1999).

Audrino and Tetereva (2019) show such a cross-over from sentiments to return, wherein sentiments in other sectors are shown to predict future stock returns. Similarly, the impact of CRE sentiments on REIT returns was recently documented (Das et al., 2015). Both housing and CRE markets are correlated with output growth and house prices exhibiting a strong correlation with lagged and contemporaneous CRE prices (Kan et al., 2004). Duca and Ling (2020) show a strong correlation between CRE prices and the overall capital markets. Prices deviate from their intrinsic values in both distressed (low-sentiment) and booming (high-sentiment) market phases (Yu and Yuan, 2011). Moreover, price bubbles in different asset markets, such as housing and CRE markets, evolve nearly in parallel (see, e.g., Cotter et al., 2018). Similarly, we see increasing asset co-movements during periods of financial turmoil (see, e.g., Bekaert et al., 2014). Based on this synthesis, we develop our third hypothesis.

Hypothesis 3. Being the least efficient market, returns in the housing market are affected by sentiments in all other markets. In contrast, because CRE markets are dominated by sophisticated investors and stock markets are most efficient, their returns are not affected by sentiments in other markets.

\section{Empirical framework}

We adopt a three-step process to examine the cross-over between sentiment and returns in the two private real estate assets and the public stock market. First, we break down the raw sentiment measures into rational and irrational components using OLS regressions. Second, we reduce the dimensionality of the irrational components by collapsing them into indices using principal component analysis (PCA). Finally, we analyze the bi-directional dependence between estimated sentiment indices and returns in the three markets using vector autoregressive (VAR) models based on quarterly data.

\subsection{Estimating composite sentiment measures}

To extract the irrational component, we regress each raw measure of sentiment on a set of relevant macroeconomic fundamentals based on the methods used by Baker and Wurgler (2006, 2007):

$\operatorname{PROXY}_{i t}=\alpha_{i}+\sum_{i=1}^{n} \beta_{i} F U N D_{i t}+\varepsilon_{i t}$,

where $P R O X Y_{i t}$ refers to the $i$ th raw sentiment measure in time $t$, capturing both irrational and rational expectations, $\alpha$ is the constant and $F U N D_{i t}$ denotes the collection of macroeconomic fundamentals to account for the effect of rational expectations on the raw indicators in the respective market, with their parameters $\beta$. These models control for seasonality using quarterly dummies. The residuals $\varepsilon$ capture the irrational aspect or "pure" sentiment, and are henceforth used as components of the sentiment index based 
on Baker and Wurgler (2006, 2007). Purely survey-based sentiment measures may bias the results (Füss et al., 2019) rendering indirect measures of sentiments more useful for asset pricing. Therefore, we aggregate the information captured by these residuals in one composite sentiment index using PCA.

We first include both the contemporaneous and lagged residuals to create a preliminary principal component, since we do not know which of the two indicators offers superior sentiment information. We then develop our final principal component using the measure (contemporaneous or lagged) for each proxy that shows the highest correlation with the preliminary principal component. This procedure ensures that a potential time lag between the measure and its effect on the pricing process is considered. The final principal component from residual proxies is the "composite sentiment index." We repeat the process separately for the three markets: residential and commercial real estate as well as the public stock market to account for a more general investor sentiment. ${ }^{8}$

\subsubsection{Housing market sentiment index}

The raw indices used for the residential real estate market are based on two questions from the monthly University of Michigan consumer confidence survey that ask individual consumers to detail their expectations for the housing market. Similar to Le et al. (2015), the percentage of respondents who believe that it is a "good time" to buy because they expect that "prices will increase" is used as a proxy for the housing market sentiment (Mich_princ). Moreover, the difference between the percentage of respondents who believe that it is a "good time" to invest and those who state that it is a "bad time" is included as a proxy for residential real estate investor sentiment (Mich_relinv) as well. ${ }^{9}$ As these measures are derived from a consumer confidence index they are still related to households but not to institutional investors. The third proxy in this market is a component of the Cleveland Financial Stress Index (CFSI) associated with investment in the residential real estate market (CFSIres). ${ }^{10}$ The CFSI is a daily index provided by the Federal Reserve Bank of Cleveland that tracks financial distress in six different types of financial markets in the U.S., including the real estate market, and as such indicates negative sentiment.

We follow Le et al. (2015) in the selection of macroeconomic indicators for house prices and use the following variables in levels or first differences $(\Delta)$ : civilian labor force as a proxy for young population $(\Delta p o p)$, nominal GDP $(\triangle G D P)$, nominal per capita income $(\Delta I n c p c)$, unemployment rate $(\Delta u r)$, nominal mortgage interest rate $(\Delta m r)$, and housing starts ( $\Delta$ supply). Instead of rental rates, the rent-to-price ratio (rentpr) obtained from the Lincoln Institute of Land Policy is used for the quarters up to 2015q1, and subsequently the ratio is calculated based on this approach using rental rates from FRED and the Case-Shiller house price index. In addition, the inflation rate $(\triangle C P I)$, the risk-free rate as measured by the yield on the 3-month T-bill (Tbill), the Federal Reserve Conference Board's index of leading economic indicators $(\triangle L E I)$, nominal oil prices $(\Delta o i l p)$, oil sales ( $\Delta$ oilsls), nominal industrial production $(\Delta i p)$ and nominal money supply M1 $(\Delta M 1)$ are included. The

\footnotetext{
8 Table 1 provides the description of all sentiment proxies and market fundamentals used to orthogonalize these proxies. Table A.1 in the Internet Appendix provides details on the first principal components from sentiment proxies, which serve as sentiment measures in various markets.

9 These two answers were chosen specifically by comparing the raw (i.e., nonorthogonalized) development of all four possible optimistic answers within the Michigan survey ("prices low", "prices will increase", "good investment", "times good") as well as their pessimistic counterparts with that of the residential real estate returns (i.e., the boom and bust cycles) in order to infer their viability.

${ }^{10}$ The series is based on Winans U.S. Real Estate Index which tracks the prices of new homes.
}

three housing market sentiment proxies are modeled as follows:

$$
\begin{aligned}
\text { PROXY }_{i}= & \alpha_{i}+\beta_{1} \Delta p o p+\beta_{2} \Delta G D P+\beta_{3} \Delta \text { Incpc }+\beta_{4} \Delta u r \\
& +\beta_{5} \Delta m r+\beta_{6} \Delta \text { supply }+\beta_{7} \text { rent } p r+\beta_{8} \Delta C P I+\beta_{9} \text { Tbill } \\
& +\beta_{10} \Delta L E I+\beta_{11} \Delta \text { oilp }+\beta_{12} \Delta \text { oilsls }+\beta_{13} \Delta i p \\
& +\beta_{14} \Delta M 1+\varepsilon_{i} .
\end{aligned}
$$

The first principal component, resulting in the household sentiment measure for the residential real estate market, RSIX, has the following loadings on the orthogonalized proxies:

$$
\begin{aligned}
\text { RSIX }_{t}= & -0.202 \text { CSFIres }_{t-1}^{\perp}+0.689 \text { Mich } \text { princ }_{t-1}^{\perp} \\
& +0.695 \text { Mich relinv } v_{t-1}^{\perp} .
\end{aligned}
$$

Because the outcomes of the two Michigan survey questions show a similar development over time, the first principal component is able to explain $50 \%$ of the variance in all three quarterly proxies. Both questions from the Michigan consumer survey also carry more weight within the index than the residential component of the CFSI index. ${ }^{11}$ All variables have the expected influence on the sentiment measure and affect the index with a lag of one quarter.

\subsubsection{Commercial real estate market sentiment}

To construct the investor sentiment measure for the commercial real estate market, we apply the same approach as for the housing market. The index construction uses several raw sentiment measures: the contribution of the commercial real estate sector to the Cleveland Financial Stress Indicator (CFSIcom), the number of REIT IPOs (reitipo) following Ling et al. (2014), 12 a measure of net commercial mortgage flows scaled as a percentage of GDP (mgtflw), the ratio of equity REITs to total REITs (reiteqsh), the perception of commercial loan availability from the Senior Loan Officer Survey (SLOS) and the perceived risk in commercial loan securitization (i.e., CMBS yields in excess of risk-free rate). Furthermore, we add the results on investment conditions for each of the nine commercial property types (see Table 1) from the Situs Real Estate Report by the Real Estate Research Corporation (RERC) as proxies. In this survey, investors are asked on a quarterly basis to provide their opinion on a scale ranging from worst (1) to excellent (10) conditions for investing.

We follow Ling et al. (2014) and select those macroeconomic fundamentals which reflect determinants of the required return rate in the commercial real estate market: the slope of the Treasury term structure of interest rates (termstruc) as measured by the difference between 10-year and 3-month Treasury bond returns, a measure of credit risk using the spread between the yields on BAA and AAA corporate bonds (yieldspr), the dividend yield on the S\&P500 (divyield), the three Fama-French risk factors ( $M K, S M B$, and HML), as well as the Cahart momentum factor (UMD), and the Pastor-Stambaugh liquidity factor (PSliq). Similar to the residential market, the inflation $(\triangle C P I)$, the 3-month T-bill yield (Tbill) and the rent-to-price ratio (rentpr) are included as well. We use the following model specification:

$$
\begin{aligned}
\text { PROXY }_{i}= & \alpha_{i}+\beta_{1} \text { termstruc }+\beta_{2} \text { yieldspr }+\beta_{3} \text { divyield }+\beta_{4} \text { PSliq } \\
& +\beta_{5} \Delta C P I+\beta_{6} \text { Tbill }+\beta_{7} M K+\beta_{8} S M B+\beta_{9} H M L \\
& +\beta_{10} U M D+\beta_{11} \text { rent pr }+\varepsilon_{i} .
\end{aligned}
$$

In an intermediary step, we combine the information from the nine RERC investment conditions in a principal component, resulting in a new variable (aggregated) RERC for all property types,

\footnotetext{
11 Note that the CFSI is a "fear" indicator, and as such holds negative weight in the index.

${ }^{12}$ The variable reitipo is only available on a quarterly basis. Hence, the specification in (8) refers to the quarterly data. However, we also extend the model to monthly data in order to test the robustness of our estimation results.
} 
Table 1

Variable definitions and descriptive statistics.

\begin{tabular}{|c|c|c|c|c|c|c|}
\hline Variable & Definition & Source & Min & Max & Mean & SD \\
\hline \multicolumn{7}{|c|}{ Return Measures } \\
\hline CRER & NCREIF Property Index (NPI) & NCREIF & -8.29 & 5.43 & 2.41 & 2.40 \\
\hline RRER & S\&P/Case-Shiller U.S. National Home Price Index & FRED & -5.47 & 5.39 & 1.26 & 2.58 \\
\hline SMTR & S\&P 500 Stock Market Index & FRED & -26.52 & 14.94 & 1.60 & 7.01 \\
\hline \multicolumn{7}{|c|}{ Sentiment Indicators } \\
\hline CFSIres & Contributions to Cleveland Financial Stress Index: Residential Real Estate Spread & FRED & 0.04 & 4.67 & 2.11 & 1.35 \\
\hline CFSIcom & $\begin{array}{l}\text { Contributions to Cleveland Financial Stress Index: Commercial Real Estate } \\
\text { Spread }\end{array}$ & FRED & 0.01 & 2.04 & 0.86 & 0.61 \\
\hline CMBS & CMBS total return index in excess of the 3-month T-bills rate & Bloomberg & -15.2 & 12.3 & -0.53 & 4.15 \\
\hline reitipo & Number of REIT Equity IPOs in a given quarter & NCREIF & 0.00 & 7.00 & 1.45 & 1.63 \\
\hline reiteqsh & Share of net REIT equity issues relative to total REIT capital raised & Federal Fund Flows & -5.33 & 5.26 & 0.26 & 1.02 \\
\hline mgtflw & Net commercial mortgage flows as percentage of GDP & Federal Fund Flows & -0.05 & 0.09 & 0.03 & 0.03 \\
\hline Mich_princ & Percentage of respondents expecting house prices to increase & University of Michigan & 1.00 & 12.00 & 5.72 & 3.10 \\
\hline Mich_relinv & Difference between responses "good time to invest" versus "bad time" & University of Michigan & 0.00 & 12.00 & 5.12 & 2.98 \\
\hline TED & $\begin{array}{l}\text { Difference between 3-month interbank loans interest rates and the 3-month } \\
\text { T-bills rate }\end{array}$ & FRED & 0.15 & 2.45 & 0.50 & 0.40 \\
\hline AAII & $\begin{array}{l}\text { American Association of Individual Investors Index, ratio bullish to bearish } \\
\text { responses }\end{array}$ & Quandl (AAII) & -0.23 & 0.63 & 0.09 & 0.18 \\
\hline VRSP & $\begin{array}{l}\text { Difference between the expected variance captured by the implied volatility } \\
\text { index (VIX) and the subsequent actual variance based on the SMTR, averaged } \\
\text { per quarter }\end{array}$ & FRED / Quandl (S\&P 500) & -4.59 & 1.43 & -0.54 & 1.51 \\
\hline IPO & Number of IPOs in a given month & Ritter, Renaissance & -101.6 & 77.8 & 20.0 & 41.9 \\
\hline CEFD & Average difference between the NAV and of closed-end fund and market prices & Lipper & -3.48 & 15.0 & 6.26 & 4.35 \\
\hline RERC & Investor ratings of investment conditions for commercial property & Situs/RERC & 3.50 & 6.46 & 5.53 & 0.68 \\
\hline SLOS & Senior Loan Officer Opinion Survey on Bank Lending Practice* & FRED & -23.7 & 87.0 & 13.6 & 27.6 \\
\hline \multicolumn{7}{|c|}{ Macroeconomic and Financial Variables } \\
\hline Tbill & 3-month Treasury bill: Secondary market rate & FRED & 0.01 & 6.02 & 2.26 & 2.12 \\
\hline termstruc & Difference between 10 -year and 3-month treasury constant maturity & FRED & -0.63 & 3.61 & 1.77 & 1.19 \\
\hline yieldspr & Difference between Moody's Seasoned Baa and Aaa corporate bond yield & FRED & 0.56 & 3.02 & 1.01 & 0.44 \\
\hline infl & Change (\%) in the Consumer Price Index & FRED & -2.29 & 1.54 & 0.54 & 0.54 \\
\hline PSliq & Pastor-Stambaugh liquidity factor & Pastor-Stambaugh & -0.10 & 0.10 & 0.00 & 0.04 \\
\hline divyield & SMTR dividend yield & Quandl (S\&P 500) & 1.12 & 3.42 & 1.80 & 0.41 \\
\hline$M K$ & Fama\&French risk factor Market Excess Return & Kenneth R. French & -7.78 & 6.46 & 0.56 & 3.02 \\
\hline$S M B$ & Fama\&French risk factor Small Minus Big & Kenneth R. French & -3.52 & 3.91 & 0.24 & 1.65 \\
\hline$H M L$ & Fama\&French risk factor High Minus Low & Kenneth R. French & -6.06 & 8.05 & 0.20 & 2.15 \\
\hline$U M D$ & Risk factor: Momentum & Kenneth R. French & -13.9 & 8.13 & 0.42 & 3.12 \\
\hline rentpr & Owners' equivalent rent of primary residence $\div$ Case-Shiller house prices & Lincoln Institute & 3.11 & 4.93 & 4.17 & 0.53 \\
\hline$\Delta p o p$ & Change (\%) in the civilian labor force & FRED & -0.40 & 1.71 & 0.22 & 0.30 \\
\hline$\triangle G D P$ & Change (\%) in the nominal Gross Domestic Product & Macroadvisers & 0.00 & 1.00 & 0.14 & 0.34 \\
\hline$\Delta \operatorname{Incpc}$ & Change (\%) in the nominal disposable personal income per capita & FRED & -6.30 & 4.40 & 0.44 & 1.32 \\
\hline$\Delta u r$ & Change (\%) in the civilian unemployment rate & FRED & -7.50 & 20.3 & 0.15 & 5.19 \\
\hline$\Delta m r$ & Change in the 30-Year Conventional Mortgage Rate & FRED & -13.8 & 20.3 & -0.80 & 5.30 \\
\hline$\Delta$ supply & Change (\%) in the number of new privately-owned housing units completed & FRED & -23.0 & 17.0 & -0.23 & 6.96 \\
\hline$\triangle L E I$ & Change in the Leading Index & FRED & -1.13 & 1.31 & 0.00 & 0.41 \\
\hline$\Delta o i l p$ & Change (\%) in the US regular all formulations gas price & FRED & -40.8 & 28.9 & 1.65 & 11.2 \\
\hline Doilsls & Change (\%) in retail trade from gasoline stations & FRED & -27.4 & 12.8 & 1.28 & 5.86 \\
\hline$\Delta M 1$ & Change (\%) in the M1 money stock & FRED & -1.20 & 7.30 & 1.40 & 1.64 \\
\hline$\Delta i p$ & Change (\%) in the industrial production index & FRED & -5.60 & 2.50 & 0.38 & 1.37 \\
\hline$\Delta$ nondurab & Change (\%) in personal consumption expenditures on nondurable goods & FRED & -7.49 & 3.30 & 1.02 & 1.51 \\
\hline$\Delta d u r a b$ & Change (\%) in personal consumption expenditures on durable goods & FRED & -7.88 & 7.79 & 0.94 & 2.22 \\
\hline$\Delta \operatorname{serv}$ & Change (\%) in personal consumption expenditures on services & FRED & -0.58 & 2.41 & 1.20 & 0.51 \\
\hline comrec & Dummy variable signifying in recessionary period in commercial real estate & NCREIF & 0.00 & 1.00 & 0.05 & 0.23 \\
\hline resrec & Dummy variable signifying in recessionary period in residential real estate & FRED & 0.00 & 1.00 & 0.07 & 0.07 \\
\hline GDPrec & Dummy variable signifying in recessionary period in overall economy & NBER & 0.00 & 1.00 & 0.11 & 0.03 \\
\hline
\end{tabular}

All descriptive statistics are based on 74 quarterly observations collected between 1997 and 2015.

* The data is based on "Measures of Supply and Demand for Commercial Real Estate Loan" series. Until 2013, the data is based on "all loans category which is discontinued afterwards". Therefore, for later years, we collect data on "Construction and Land Development" category afterwards. All variables are stationary except the following for which the Augmented Dickey-Fuller (ADF) Test had p-values greater than 0.05: $\Delta$ ur, $\Delta$ supply, rentpr, termstruc, divyield, gdprec.

which we use in the subsequent PCA together with the other sentiment components. In the next step, PCA is employed on all orthogonalized variables, as shown in Eq. (8), to arrive at the following quarterly CRE investor sentiment measure, CSIX:

$$
\begin{aligned}
& \text { CSIX }_{t}=-0.437 \text { CFSIcom } \\
&+-0.319 m g \text { f fl } w_{t-1}^{\perp}-0.509 R E R C_{t-1}^{\perp}+0.420 \text { CMBS }_{t-1}^{\perp} \\
&+0.369 \text { SLOS } \\
& \hline t-1
\end{aligned}
$$

For CSIX, 31\% of the proxies' variance is explained by the first principal component. The RERC investment conditions as well as the mortgage flows have the strongest impact on the resulting sentiment index. The equity share in REITs has a negative influence on the index, which is unexpected, but well documented in Baker and Wurgler (2007). Das et al. (2015) explain this finding by the "flight to liquidity" phenomenon among commercial real estate investors.

\subsubsection{Stock market sentiment index}

We also construct a sentiment index for the stock market to analyze whether general investor sentiment affects returns and sentiment in the two real estate markets. The raw stock market sentiment index includes the TED spread (TED), i.e. the difference between interest rates on 3-month interbank loans and the 3-month T-bill rate, as a proxy for default and liquidity risk. A smaller credit spread implies higher confidence in the economy. Based on S\&P 500 stock market returns (SMTR), we use implied 
volatility in excess of the actual volatility in the stock market (VRSP) calculated as the quarterly average of daily observations. As such, positive VRPS (i.e., the difference between the implied volatility index VIX and the subsequent actual variance based on the SMTR) represents higher risk expectations than justified by the market and can be interpreted as negative investor sentiment. Furthermore, we include results from the American Association of Individual Investors (AAII) survey, using the ratio of bullish to bearish investors as the proxy for sentiment (AAII), the number of REIT IPOs (reitipo) and the average first-day returns of these IPOs, as well as the Closed-End Fund Discount (CEFD).

For the public stock markets, we select the fundamental macroeconomic variables following Baker and Wurgler (2006). Economic growth is proxied by the personal consumption of services $(\Delta$ serv), durable ( $\Delta$ durab) and non-durable goods ( $\Delta$ nondurab), as well as by the change in the nominal industrial production index $(\Delta i p)$. In addition, we also include regressors such as inflation $(\triangle C P I)$ and the percentage change in the supply of new homes ( $\Delta$ supply). Each proxy is orthogonalized based on the following regression in order to derive the "pure" sentiment:

$$
\begin{aligned}
\operatorname{PROXY}_{i}= & \alpha_{i}+\beta_{1} \Delta \operatorname{ser} v+\beta_{2} \Delta \text { durab }+\beta_{3} \Delta \text { nondurab }+\beta_{4} \Delta i p \\
& +\beta_{5} \Delta C P I+\beta_{6} \Delta \text { supply }+\varepsilon_{i} .
\end{aligned}
$$

Due to the significant correlation, we aggregate the information from the two IPO variables (i.e. the number of IPOs and the average first-day returns of these IPOs) in one principal component, resulting in a new IPO factor (reitipo). We create the quarterly aggregate sentiment index for the (public) stock market sentiment (SSIX) from the first principal component of the regression residuals, with the following loadings on either the contemporaneous or lagged proxy:

$$
\begin{aligned}
\operatorname{SSIXq}_{t}= & 0.57 T E D_{t-1}^{\perp}-0.22 A A I I_{t}^{\perp}-0.51 \text { reitipo }_{t}^{\perp}+0.57 C E F D_{t}^{\perp} \\
& +0.23 \operatorname{VRSP}_{t}^{\perp} .
\end{aligned}
$$

The first principal component explains $40 \%$ of the variation in the five remaining public investor sentiment proxies. The relatively high percentage can be attributed to the fact that all proxy measures are market-based, with the exception of AAII, which has a relatively low weight in the index. All measures show the expected sign on their loadings and affect the index as predicted. The time structure of the proxies is similar to Baker and Wurgler (2006), with the proxies "based directly on investor demand or investor behavior" showing a contemporaneous $(t)$ effect and the supply variable $(T E D)$ having a lagged $(t-1)$ impact.

\subsection{Vector autoregressive model (VAR)}

Based on earlier studies (Brown and Cliff, 2005; Ling et al., 2014), we are interested in the inter-relations between the two private real estate markets as well as in their relationships with public stock markets. We estimate the interdependence within a system of equations based on a vector autoregressive (VAR) model:

$$
\begin{aligned}
\text { ret }_{t, j} & =\mu_{1, j}+\sum_{i=1}^{p} \beta_{1 i, j} \text { ret }_{t-i, j}+\sum_{i=1}^{p} \gamma_{1 i, j} \text { sent }_{t-i, j}+\delta_{1, j} X_{t, j}+\varepsilon_{1 t, j} \\
\text { sent }_{t, j} & =\mu_{2, j}+\sum_{i=1}^{p} \beta_{2 i, j} \text { ret }_{t-i, j}+\sum_{i=1}^{p} \gamma_{2 i, j} \text { sent }_{t-i, j}+\delta_{2, j} X_{t, j}+\varepsilon_{2 t, j} .
\end{aligned}
$$

The variable ret captures the nominal percentage change in the prices of $j=1,2,3$ markets (housing, commercial properties, and stocks) and sent denotes the corresponding sentiment proxies. $\mu_{1}$ and $\mu_{2}$ are the intercepts and $X$ is a matrix of exogenous control variables for the fundamental determinants of returns including the $\triangle G D P, \Delta u r$, and $\Delta i p .^{13}$

The Augmented Dickey Fuller (ADF) test shows that some variables are non-stationary in levels, but mostly stationary in their first differences. Based on a break-point analysis (Bai and Perron, 2003), we find that the subprime crisis induces a unit root process in commercial real estate, which is otherwise stationary. Therefore, we introduce a dummy variable capturing the financial crisis and the great recession period from 2007q1 to 2012q1 as an exogenous variable (GDPrec), which is highly significant in all models. However, recessionary periods differ across asset classes. The subprime crisis, for example, started with the housing market, followed by the CRE and eventually the economic recession. Therefore, we control separately for residential (resirec) and commercial (comrec) recession periods.

We ensure the validity of the estimated VAR models by testing the error terms for autocorrelation, heteroscedasticity, and nonnormality, and by checking the stability condition of the eigenvalues. Further, we apply the Granger causality test, orthogonal impulse response functions (IRF), and derive one-step-ahead forecasts from the estimated VAR models.

\section{Data}

For prices in the residential real estate market, we use Standard \& Poor's/Case-Shiller U.S. National Home Price Index as a proxy. The change in the log index values is used as the continuously compounded return measure for the private housing market. Similarly, the log differences in the property index of National Council of Real Estate Investment Fiduciaries (NCREIF) as well as in the S\&P 500 index are used as proxies for commercial real estate and stock market returns, respectively. ${ }^{14}$ We use quarterly data and our sample period spans from $1997 q 2$ to $2015 q 4$.

\subsection{Sentiment indices}

As shown in Eqs. (5) to (10), the composite sentiment in a market is calculated as a principal component of multiple proxies which are first orthogonalized by market fundamentals. Orthogonalization refers to recording the residuals from an OLS regression of a sentiment proxy when regressed over a set of market fundamentals. Each residual series, i.e. each "pure" sentiment proxy, is then standardized with a mean of zero and variance of unity. However, the resulting commercial real estate sentiment index (CSIX), i.e. first principal component, has a wider range of values and is thus more volatile, with a standard deviation of 1.36 , a minimum value of -4.52 and a maximum value of 4.85 , while the residential real estate sentiment index (RSIX) stays within a range of -3.24 and 2.30 with a slightly lower standard deviation of 1.22 . This difference could simply be explained by the fact that the commercial real estate market is more volatile or by the fact that its investors update their behavioral perceptions more dynamically than in the residential real estate market. Stock market sentiment (SSIX), lastly, does not have a large value range ( -4.16 to 2.49 ), but has a higher standard deviation (1.48) than both real estate sentiment factors. CSIX, RSIX, and SSIX are stationary at the $1 \%$ and $5 \%$ significance level, respectively, and enter the VAR equations in levels as shown in Fig. 1.

\footnotetext{
13 Note that we have already controlled for fundamental factors in our "pure" sentiment variables. Hence, we assume that these factors are insignificant in the VAR equations for market sentiments.

${ }^{14}$ Due to data availability, we primarily rely on the NPI. However, in unreported robustness tests we rerun our model based on a transaction-based index to validate its results.
} 


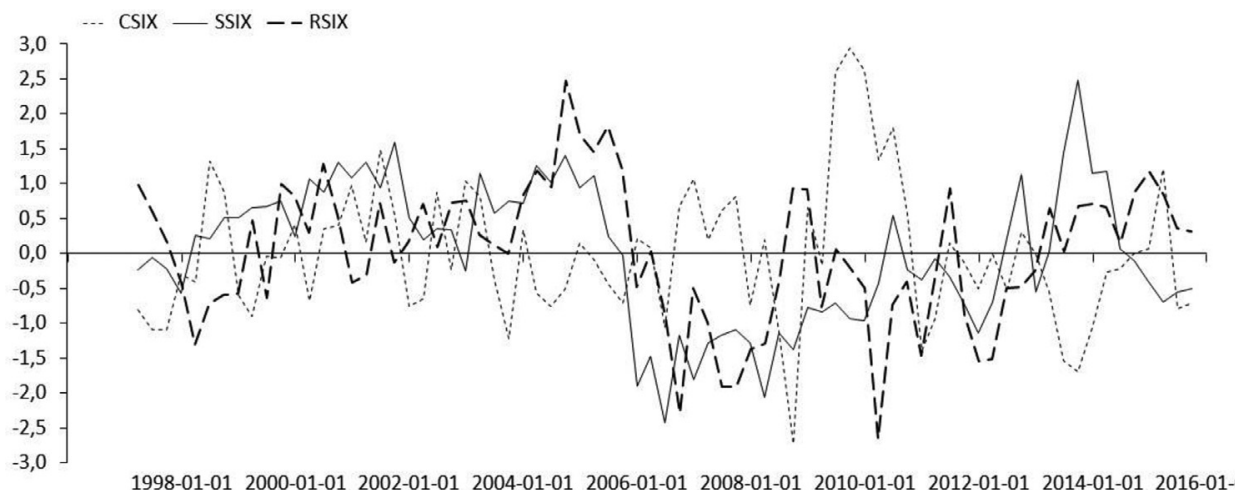

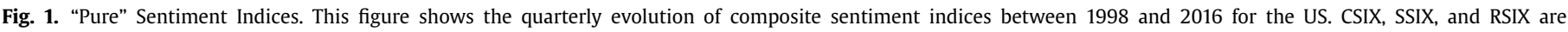

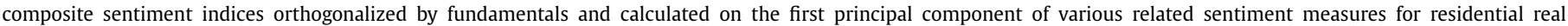
estate, commercial real estate and public equity, respectively.

Fig. 1 describes the evolution of our composite sentiment indices in the three markets over time. CSIX is more volatile than RSIX, and SSIX is the least volatile sentiment index. However, these two indices may be prone to smoothing due to lower frequencies of being recorded (quarterly or monthly). We observe that CSIX led other sentiment indices during the early years (e.g., the dotcom crisis around 2000) and RSIX is the most sluggish indicator. During the pre-crisis bubble era (around 2004), SSIX and RSIX tend to co-move, but are still led by CSIX. In the subprime and subsequent global financial crisis period from 2006 to 2008 stock market sentiment reacts first, followed by the residential market. Our sentiment indices demonstrate strong validity as they turn negative during the crisis period. ${ }^{15}$ In the post-crisis era, we do not detect a distinct lead-lag phenomenon across the three sentiment types.

Table 1 shows the summary statistics and definitions for the return measures, the sentiment proxies, as well as macroeconomic control variables for our sample period on a quarterly basis.

The broad perspective on sentiment that we take in this study allows us to examine the relationship among different types of sentiment indices as well as their components for the first time. Table 2 shows the correlation matrices for the return measures, the sentiment indices, and the raw sentiment proxies. Since the sentiment measures are built on the basis of a principal component analysis of the various sentiment proxies, these variables show a strong correlation with their respective sentiment index by construction.

For the residential real estate sentiment index RSIX, both questions (regarding "house price" and "good time to invest") from the Michigan Survey of Consumers are highly positively correlated, while the CFSI fear index shows a negative correlation, as expected. We do not detect a significant correlation between RSIX and residential returns (RRER). The commercial real estate sentiment index CSIX exhibits significantly negative correlation with sentiment measures such as investors' ratings of investment conditions for commercial property (RERC), mortgage flow (mgtflow), number of REIT IPOs (reitipo) and significantly positive correlation with Financial Stress Index (CFSIcom), excess CMBS returns (CMBS), and the equity share in new REIT issues (reiteqsh). Note that according to the index construction, a negative correlation with the measures encourages investments, while positive correlation is known to reflect increased risk in debt capital, which makes CSIX a measure of negative sentiment (pessimism). The stock market sentiment index SSIX is highly correlated with several of its raw proxies, ex-

\footnotetext{
15 Note that sentiment in the commercial real estate market (CSIX) results by construction in a measure of pessimism, and thus, shows positive values during the crisis period.
}

cept with the CEFD measure. Since SSIX mainly consists of marketbased variables, this is not surprising. ${ }^{16}$ The number of IPOs (reitipo) shows an unexpected, negative correlation with the sentiment measure, but, as expected, its fluctuation mirrors that of the other raw proxies. ${ }^{17}$ Once combined into one factor, the IPO factor shows the expected positive correlation with the index. TED and VRPS, both measures of risk on the market, are also highly correlated with each other.

The measures of sentiment within the real estate markets (not reported in Table 2) show a relatively high correlation of 0.30 while their correlation with the stock market sentiment index is very low. The correlation coefficient between RSIX and SSIX is 0.07, while that between CSIX and SSIX is in fact slightly negative with -0.09 . This implies that real estate investors seem to have a similar tendency to react to news, while potentially being quite independent of the sentiment of investors on other financial markets. This fact might indicate that the real estate sentiment measures have a cross-over effect on returns in the other markets as well as on each other, while the public market sentiment factor might not have such an effect. These observations confirm the findings of Freybote and Seagraves (2018), who use the heterogeneity of investors to show that sentiment of specialized real estate (such as REIT) investors has a cross-over effect on the sentiment of multiasset investors such as pension and insurance funds but not vice versa. Yet, in the absence of control variables (which we present later) these findings are preliminary indications only. We elaborate on these cross-over effects between residential and commercial real estate as well as the general stock market sentiment in the next section.

\section{Estimation results}

\subsection{Vector autoregressive regression (VAR)}

Table 3 presents the VAR regression results of the base model with sentiments (RSIX, CSIX, and SSIX) and returns (RRER, CRER, and SMTR) in the three markets (residential, CRE and stock market) as endogenous variables. The information criteria developed by Hannan-Quinn (HQ) and Schwarz-Bayesian (SB) suggest using one lag, while the remaining serial correlation in the residuals demands for a higher lag structure. We run the analysis using three-

\footnotetext{
16 The share turnover is an anomaly also found in the monthly sample, but the variable is retained since it provides some additional validity in the quarterly models.

17 The number of IPOs and their average first-day returns are not included as variables in the correlation table, as they were not used in the regressions in their final form but were aggregated into one IPO factor.
} 
Table 2

Correlation tables.

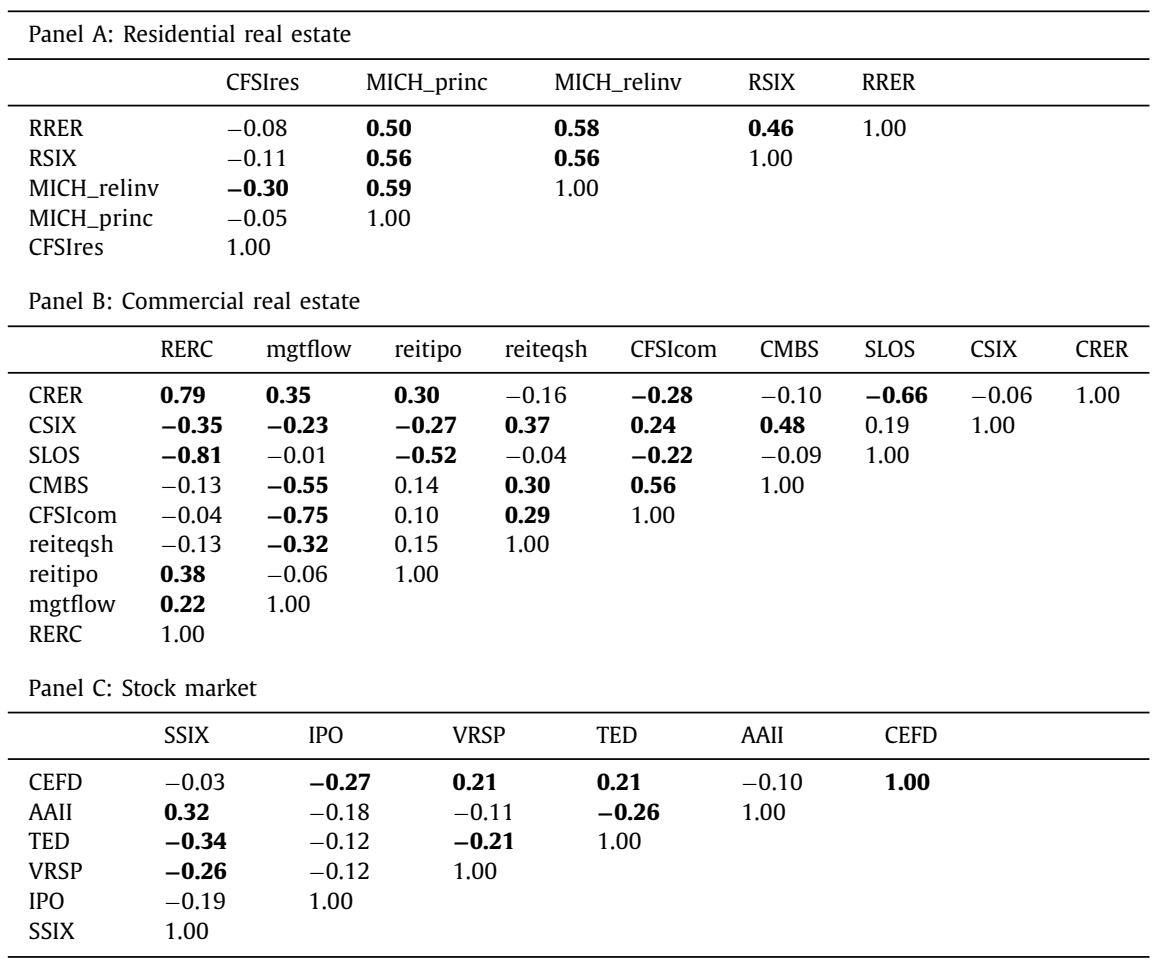

This table shows the correlation structure between the variables used in the regressions for the residential and commercial real estate market, as well as the public market in Panels A, B, and C, respectively. Bold numbers denote significance at least at the $10 \%$ level. CFSIres refers to Contributions to Cleveland Financial Stress Index: Residential Real Estate Spread, CFSIcom refers to Contributions to Cleveland Financial Stress Index: Commercial Real Estate Spread, SLOS refers to Senior Loan Officer Opinion Survey rating on Bank Lending Practice, CMBS equals the CMBS total return index in excess of the 3-month T-bills rate, reitipo equals the number of REIT Equity IPOs in a given quarter, reiteqsh equals the Share of net REIT equity issues relative to total REIT capital raised, mgtflw refers to net commercial mortgage flows as percentage of GDP, RERC is commercial real estate investment sentiment, TED is the difference between 3-month interbank loans interest rates and the 3-month T-bills rate, AAII refers to the American Association of Individual Investors Index (the ratio of bullish to bearish responses), IPO is the number of IPOs in a given month, CEFD equals the average difference between the NAV and of closed-end fund and market prices, VRSP is the difference between the expected variance captured by the market volatility index (VIX) and the subsequent actual variance based on the S\&P 500 returns, averaged per quarter. RSIX, CSIX, and SSIX are composite sentiment indices orthogonalized by fundamentals and calculated on the first principal component of various related sentiment measures for residential real estate, commercial real estate, and public equity, respectively.

lag structure (in Table A.2 of the Appendix), however, the results do not differ significantly. Therefore, for brevity, we report the 1lag VAR model (as follows) and include the results from a more comprehensive, 3-lag model in the Appendix.

\subsubsection{Market sentiments}

Broadly, the sentiment proxies are not affected by most exogenous factors (Models 1, 2 and 3), because the composite sentiment measures have already been orthogonalized by macroeconomic variables. In Model 1, residential sentiment (RSIX) is negatively associated with lagged commercial sentiment and weakly, but positively associated with stock market sentiment (SSIX). Because CSIX reflects negative sentiment, as the components of the CSIX composite in Eq. (8) indicate, a negative coefficient implies that residential sentiment co-moves with both the lagged commercial and public stock market sentiments. We also detect a significant association with lagged return in the residential market (RRER). As reported in Model (2), beyond a significant effect of the commercial returns (CRER), the commercial sentiment measure evolves independently of other endogenous variables in the system. This finding is in line with our Hypothesis 2.

CSIX is not affected by other market returns or sentiments, but exhibits autoregression and is associated with lagged CRER. Our finding is partially supportive of Hypothesis 2 that CSIX is not affected by the residential market. However, insignificance of SSIX (and SMTR) in determining the CSIX affirms that institutionallydominated CRE investor sentiments evolve independent of other markets and their irrationality is limited to the CRE investment space. Our finding suggests that CRE investors are driven by market-specific behavior that is more disconnected from other market sentiments than hypothesized.

Stock market sentiments (SSIX) are significantly associated with lagged residential sentiments and return measures (Model 3), but do not exhibit any significant association with lagged commercial real estate markets (returns or sentiments). The system of variables explains $35-65 \%$ of variation in these three sentiment measures according to the adjusted $R$-squared of the individual models. This finding reflects the fact that beyond the impact of endogenous sentiment measures, irrational market sentiments evolve independently. It is partially supportive of our Hypothesis 2, wherein stock market sentiments are affected by both residential and CRE markets.

As our sentiment measures are not informed by facts at hand, they reflect how investors in the three segments perceive other markets. The noticeable cross-over between residential and public equity markets reflects the widely-held belief that housing and 
Table 3

Results from $\operatorname{VAR}(1)$ estimations.

\begin{tabular}{|c|c|c|c|c|c|c|}
\hline & \multicolumn{6}{|c|}{ Dependent variable: } \\
\hline & \multicolumn{3}{|c|}{ Market sentiment } & \multicolumn{3}{|c|}{ Market returns } \\
\hline & $\begin{array}{l}1 \\
\text { RSIX }\end{array}$ & $\begin{array}{l}2 \\
\text { CSIX }\end{array}$ & $\begin{array}{l}3 \\
\text { SSIX }\end{array}$ & $\begin{array}{l}4 \\
\text { RRER }\end{array}$ & $\begin{array}{l}5 \\
\text { CRER }\end{array}$ & $\begin{array}{l}6 \\
\text { SMTR }\end{array}$ \\
\hline RSIX.11 & $\begin{array}{l}\text { 0.333*** } \\
(0.110)\end{array}$ & $\begin{array}{l}-0.072 \\
(0.133)\end{array}$ & $\begin{array}{l}-\mathbf{- 0 . 2 8 7}^{*} \\
(0.144)\end{array}$ & $\begin{array}{l}0.056 \\
(0.151)\end{array}$ & $\begin{array}{l}-0.0003 \\
(0.001)\end{array}$ & $\begin{array}{l}-0.679 \\
(0.905)\end{array}$ \\
\hline CSIX.11 & $\begin{array}{l}-\mathbf{0 . 2 3 2} 2^{* *} \\
(0.092)\end{array}$ & $\begin{array}{l}\text { 0.236** } \\
(0.111)\end{array}$ & $\begin{array}{l}-0.115 \\
(0.121)\end{array}$ & $\begin{array}{l}-\mathbf{0 . 2 6 2}^{* *} \\
(0.127)\end{array}$ & $\begin{array}{l}0.002 \\
(0.001)\end{array}$ & $\begin{array}{l}\mathbf{1 . 5 2 4}^{* *} \\
(0.759)\end{array}$ \\
\hline SSIX.11 & $\begin{array}{l}\mathbf{0 . 1 9 0}^{* *} \\
(0.079)\end{array}$ & $\begin{array}{l}-0.137 \\
(0.096)\end{array}$ & $\begin{array}{l}\text { 0.604*** } \\
(0.104)\end{array}$ & $\begin{array}{l}0.109 \\
(0.109)\end{array}$ & $\begin{array}{l}-0.001 \\
(0.001)\end{array}$ & $\begin{array}{l}0.527 \\
(0.653)\end{array}$ \\
\hline RRER.11 & $\begin{array}{l}\mathbf{0 . 1 4 3}^{* *} \\
(0.062)\end{array}$ & $\begin{array}{l}0.005 \\
(0.075)\end{array}$ & $\begin{array}{l}\mathbf{0 . 2 5 1}^{* * * *} \\
(0.081)\end{array}$ & $\begin{array}{l}\mathbf{0 . 8 2 2}^{* * * *} \\
(0.085)\end{array}$ & $\begin{array}{l}0.001 \\
(0.001)\end{array}$ & $\begin{array}{l}-0.688 \\
(0.507)\end{array}$ \\
\hline CRER.11 & $\begin{array}{l}-5.307 \\
(5.476)\end{array}$ & $\begin{array}{l}-18.097^{* * *} \\
(6.631)\end{array}$ & $\begin{array}{l}-12.027 \\
(7.198)\end{array}$ & $\begin{array}{l}-25.327^{* * *} \\
(7.538)\end{array}$ & $\begin{array}{l}\mathbf{0 . 7 6 3} * * * \\
(0.075)\end{array}$ & $\begin{array}{l}-13.005 \\
(45.153)\end{array}$ \\
\hline SMTR.11 & $\begin{array}{l}0.001 \\
(0.016)\end{array}$ & $\begin{array}{l}-0.013 \\
(0.019)\end{array}$ & $\begin{array}{l}0.004 \\
(0.021)\end{array}$ & $\begin{array}{l}\mathbf{0 . 0 4 8}^{* *} \\
(0.022)\end{array}$ & $\begin{array}{l}0.00002 \\
(0.0002)\end{array}$ & $\begin{array}{l}0.134 \\
(0.131)\end{array}$ \\
\hline const & $\begin{array}{l}0.111 \\
(0.238)\end{array}$ & $\begin{array}{l}0.420 \\
(0.289)\end{array}$ & $\begin{array}{l}-0.096 \\
(0.313)\end{array}$ & $\begin{array}{l}\text { 0.798*** } \\
(0.328)\end{array}$ & $\begin{array}{l}0.0004 \\
(0.003)\end{array}$ & $\begin{array}{l}0.509 \\
(1.965)\end{array}$ \\
\hline$\triangle G D P$ & $\begin{array}{l}-0.309 \\
(0.186)\end{array}$ & $\begin{array}{l}0.096 \\
(0.225)\end{array}$ & $\begin{array}{l}0.345 \\
(0.244)\end{array}$ & $\begin{array}{l}0.184 \\
(0.256)\end{array}$ & $\begin{array}{l}0.004 \\
(0.003)\end{array}$ & $\begin{array}{l}\text { 4.442*** } \\
(1.532)\end{array}$ \\
\hline$\Delta u r$ & $\begin{array}{l}0.041 \\
(0.030)\end{array}$ & $\begin{array}{l}0.044 \\
(0.037)\end{array}$ & $\begin{array}{l}-0.006 \\
(0.040)\end{array}$ & $\begin{array}{l}0.008 \\
(0.042)\end{array}$ & $\begin{array}{l}-0.0005 \\
(0.0004)\end{array}$ & $\begin{array}{l}-\mathbf{0 . 5 0 6}^{* *} \\
(0.250)\end{array}$ \\
\hline$\Delta I n c p c$ & $\begin{array}{l}0.045 \\
(0.138)\end{array}$ & $\begin{array}{l}0.183 \\
(0.167)\end{array}$ & $\begin{array}{l}-\mathbf{0 . 3 0 6}^{*} \\
(0.182)\end{array}$ & $\begin{array}{l}-0.051 \\
(0.190)\end{array}$ & $\begin{array}{l}\mathbf{0 . 0 0 4}^{*} \\
(0.002)\end{array}$ & $\begin{array}{l}-0.546 \\
(1.140)\end{array}$ \\
\hline resirec & $\begin{array}{l}0.006 \\
(1.031)\end{array}$ & $\begin{array}{l}-2.353^{*} \\
(1.249)\end{array}$ & $\begin{array}{l}-0.558 \\
(1.356)\end{array}$ & $\begin{array}{l}-1.800 \\
(1.420)\end{array}$ & $\begin{array}{l}0.022 \\
(0.014)\end{array}$ & $\begin{array}{l}12.295 \\
(8.504)\end{array}$ \\
\hline comrec & $\begin{array}{l}1.054 \\
(0.850)\end{array}$ & $\begin{array}{l}0.020 \\
(1.030)\end{array}$ & $\begin{array}{l}0.332 \\
(1.118)\end{array}$ & $\begin{array}{l}0.655 \\
(1.171)\end{array}$ & $\begin{array}{l}-\mathbf{0 . 0 3 7 * * *} \\
(0.012)\end{array}$ & $\begin{array}{l}-16.854^{* *} \\
(7.011)\end{array}$ \\
\hline GDPrec & $\begin{array}{l}-0.682 \\
(0.420)\end{array}$ & $\begin{array}{l}0.765 \\
(0.508)\end{array}$ & $\begin{array}{l}0.007 \\
(0.552)\end{array}$ & $\begin{array}{l}-0.150 \\
(0.578)\end{array}$ & $\begin{array}{l}0.006 \\
(0.006)\end{array}$ & $\begin{array}{l}-2.229 \\
(3.460)\end{array}$ \\
\hline Observations & 72 & 72 & 72 & 72 & 72 & 72 \\
\hline$R^{2}$ & 0.633 & 0.464 & 0.708 & 0.898 & 0.884 & 0.498 \\
\hline Adjusted $R^{2}$ & 0.558 & 0.355 & 0.648 & 0.878 & 0.861 & 0.395 \\
\hline Residual Std. Error $(\mathrm{df}=59)$ & 0.665 & 0.805 & 0.874 & 0.916 & 0.009 & 5.484 \\
\hline$F$ Statistic $(\mathrm{df}=12 ; 59)$ & $8.465^{* * * *}$ & $4.250^{* * * *}$ & $11.896^{* * *}$ & $43.392 * * *$ & $37.580^{* * *}$ & $4.871^{* * *}$ \\
\hline
\end{tabular}

This table shows the estimation results for the system of VAR including residential and commercial real estate, as well as the stock market in the US. RSIX, CSIX, and SSIX are composite sentiment indices orthogonalized by fundamentals and calculated on the first principal component of various related sentiment measures for residential real estate, commercial real estate, and public equity, respectively. Residential real estate return (RRER) and commercial real estate return (CRER) are derived from the nationally aggregated returns in the S\&P Case-Shiller Home Price Index and NCREIF property Index (NPI), respectively. SMTR is the quarterly return on S\&P 500 stock index. Exogenous controls employed in the system VAR are: the change (\%) in the Gross Domestic Product $(\triangle r G D P)$, the change (\%) in the disposable personal income per capita $(\Delta r I n c p c)$, and the change (\%) in the civilian unemployment rate $(\Delta u r)$. The model controls for recession in residential real estate (resirec), commercial real estate (comrec), and the economy (GDPrec) using the corresponding quarterly dummy variables. The sample period is $1997 \mathrm{q} 2$ to $2015 \mathrm{q} 4$. Standard errors are reported in parentheses. ${ }^{* * *},{ }^{* *}$, and $*$ represent $1 \%, 5 \%$, and $10 \%$ significance levels, respectively.

business cycle are one and the same (Leamer 2015). Remarkably, the commercial real estate sector is perceived to be independent, both by the commercial investors themselves and by investors in the other two segments. The effectiveness of modeling sentiment measures should manifest in their ability to determine return measures.

Table 3 suggests that sentiment measures in all the three segments exhibit significant positive autocorrelation. The residential (RSIX) and commercial (SSIX) sentiment measures are also intuitively guided by returns in their respective segments, although the public market sentiment (SSIX) is orthogonal to lagged stock returns. More interestingly, while CSIX evolves independently of other segments (residential and stock markets), the RSIX and SSIX sentiments exhibit significant cross-over dynamics. The next three return models examine the determinants of return measures, which suggest that sentiment cross-overs are inconsistent with return cross-overs.

\subsubsection{Market returns}

In informationally efficient markets, returns should be free of autocorrelation and the coefficients of the lagged endogenous vari- ables should be insignificant. As expected, returns in the private markets (CRER and RRER) are significantly and positively autocorrelated, whereas in the public stock market (STMR) the weak-form of market efficiency does hold. As shown in Model 4, residential real estate returns (RRER) are negatively associated with lagged commercial sentiments (CSIX). Since CSIX reflects negative sentiment, this finding suggests a positive spillover from commercial sentiment to residential returns. ${ }^{18}$ On the contrary, lagged return (CRER) in the commercial sector has a disciplining (i.e., negative) association with residential returns. The determinants of RRER in the VAR system imply that while commercial sentiments reinforce residential returns, residential investors take a contrarian view to the actual commercial market performance. Our model explains $88 \%$ of the variation in residential returns. A significantly negative coefficient of lagged commercial (negative) sentiment (CSIX) is not in line with the significantly positive coefficient of lagged commercial returns (CRER) and reflects households' asymmetric response to facts at hand and sentiments in the commercial sector. As commercial sentiments may be perceived to be more informed

\footnotetext{
18 Our VAR(3) models in Table A.2 of the Appendix also shows some association between RRER and lagged SMTR returns.
} 
than residential sentiments, a significant response to commercial sentiments reflects irrational behavior of residential investors. These findings are broadly in line with our Hypothesis 3.

As shown in Model 5, commercial returns (CRER) reflect a different dynamic. Beyond the autoregressive part, we do not detect any noticeable association with lagged returns or sentiment measures in any segment. ${ }^{19}$ However, over a longer horizon, as we show later through impulse response functions, CRER is significantly affected by CSIX, which confirms our Hypothesis 1 . The model explains $40-88 \%$ of the variation in commercial real estate returns. ${ }^{20}$ Our findings suggest a higher sensitivity of commercial investors to macroeconomic factors ( $\triangle I n c p c$, comrec). Comparing VAR models for RRER and CRER supports the notion that while residential returns are irrationally influenced by commercial sentiments, the commercial returns are broadly independent of sentiments. This result confirms our assumption that investors in the commercial real estate market are more rational. In general, we accept our Hypothesis 3 that dominated by sophisticated investors, returns in the CRE sector are not affected by sentiments in other markets.

Model 6 explains the determinants of the stock market return. We find a significant and contrarian response to commercial real estate sentiment, ${ }^{21}$ which is in line with earlier studies (Ball et al., 2002; Das et al., 2015), although the association vanishes in the VAR(3) models presented in Table A.2 of the Appendix. We find that stock markets, where both institutional and individual investors are active, are affected by CRE sentiments. The behavior is in line with the capital-switching behavior of the investors between CRE and stock markets. However, this finding is puzzling as the stock returns respond to sentiments in CRE, and not to the returns in CRE. In other words, based on this explanation while institutional investors exhibit rational behavior when investing in CRE, their significant response to irrational sentiments in the CRE market is contrary to our Hypothesis 3. An explanation for the significance of CSIX in explaining SMTR might be the proportion of individual investors in the stock market or the impact of business sentiment in the economy, which we are unable to disentangle in our empirical framework.

In sum, while commercial real estate sentiment evolves independently of the other two markets (residential and stock markets), they play a significant role in determining returns in the residential sector. On the other hand, although sentiments in the residential and public equity sectors are intertwined, they do not play a significant role in determining any return measures. This finding suggests the importance of the opinion of commercial investors in the real estate markets. In particular, commercial real estate sentiments hold significant information content for an economic system.

Due to the interdependence between the endogenous variables within the system, we cannot comprehensively interpret the overall effect of the VAR coefficients. Therefore, we further conduct Granger causality tests and impulse response functions (IRFs) to discover the dynamics in the cross-over effects. In addition, we evaluate whether sentiment improves the forecast performance of our models.

\footnotetext{
19 Through VAR(3) models, we find some weak evidence that commercial real estate returns are significantly, and negatively associated with lagged stock market sentiments affirming earlier findings that instituional investors opportunistically switch capital between these markets (Ball, Lizieri, and MacGregor, 2002; Das, Freybote, and Marcato, 2015).

${ }^{20}$ In the $\operatorname{VAR}(3)$ models of Table A.2 in the Appendix the adjusted $R$-squared is in the range of $60 \%-92 \%$.

21 Note that CSIX is a PCA composite measure which loads negatively with nonfundamental optimism.
}

Table 4

Results from Granger-causality tests.

\begin{tabular}{|c|c|c|c|c|}
\hline Cause & Effect & F-statistic & $p$-value & Significance \\
\hline CSIX & RSIX & 2.11 & 0.11 & \\
\hline SSIX & RSIX & 3.89 & 0.01 & $* * *$ \\
\hline RRER & RSIX & 1.08 & 0.36 & \\
\hline CRER & RSIX & 0.55 & 0.65 & \\
\hline SMTR & RSIX & 0.14 & 0.93 & \\
\hline RESIX & CSIX & 1.57 & 0.21 & \\
\hline SSIX & CSIX & 0.32 & 0.81 & \\
\hline RRER & CSIX & 0.84 & 0.48 & \\
\hline CRER & CSIX & 6.35 & $<0.01$ & $* * *$ \\
\hline SMTR & CSIX & 0.24 & 0.87 & \\
\hline RSIX & SSIX & 0.70 & 0.56 & \\
\hline CSIX & SSIX & 1.07 & 0.37 & \\
\hline RRER & SSIX & 2.72 & 0.05 & $* *$ \\
\hline CRER & SSIX & 0.97 & 0.41 & \\
\hline SMTR & SSIX & 0.37 & 0.77 & \\
\hline RSIX & RRER & 0.99 & 0.40 & \\
\hline CSIX & RRER & 1.18 & 0.32 & \\
\hline SSIX & RRER & 2.02 & 0.12 & \\
\hline CRER & RRER & 3.65 & 0.02 & $* *$ \\
\hline SMTR & RRER & 6.43 & $<0.01$ & $* * *$ \\
\hline RSIX & CRER & 1.64 & 0.19 & \\
\hline CSIX & CRER & 0.97 & 0.41 & \\
\hline SSIX & CRER & 2.63 & 0.06 & $*$ \\
\hline RRER & CRER & 3.74 & 0.02 & $* *$ \\
\hline SMTR & CRER & 2.29 & 0.09 & $*$ \\
\hline RSIX & SMTR & 1.09 & 0.36 & \\
\hline CSIX & SMTR & 2.42 & 0.07 & * \\
\hline SSIX & SMTR & 1.27 & 0.29 & \\
\hline RRER & SMTR & 0.36 & 0.78 & \\
\hline CRER & SMTR & 1.02 & 0.39 & \\
\hline
\end{tabular}

This table provides Granger-causality test results based on VAR(1) models. RSIX, CSIX, and SSIX are composite sentiment indices after they are orthogonalized by fundamentals and calculated on the first principal component of various related sentiment measures for residential real estate, commercial real estate, and public equity, respectively. Residential real estate return (RRER) and commercial real estate return (CRER) are derived from the nationally aggregated returns in the S\&P Case-Shiller Home Price Index and NCREIF property Index (NPI), respectively. SMTR is the quarterly return on S\&P 500 stock index. The models also control for exogenous macroeconomic variables. The sample period is $1997 q 2$ to $2015 q 4$. $^{* * *}$, ${ }^{* *}$, and ${ }^{*}$ denote statistical significance at $1 \%, 5 \%$, and $10 \%$ levels, respectively.

\subsection{Granger causality test}

In Table 4, we provide the summary of Granger causality tests across the endogenous variables in our VAR(1) system. Stock market sentiments (SSIX) significantly Granger-cause residential market sentiments (RSIX). Commercial real estate sentiment (CSIX) is only Granger-caused by commercial returns although stock market sentiment (SSIX) is Granger-caused by residential returns (RRER). Further, commercial and residential real estate show a feedback relationship in their returns (CRER and RRER), which supports our Hypothesis 1 for the two less efficient private markets.

The significant dependence structure between returns in commercial and residential real estate markets asserts the role commercial real estate plays in the wider economic system. This role is further affirmed by the significant impact that CSIX has on stock market returns, which in turn are a significant determinant of RRER returns. Further, both SSIX and SMTR significantly Grangercause CRER.

It is worthwhile to distinguish between causality and Grangercausality. Causality implies meeting some conditions: (1) all confounding factors are properly controlled for, (2) the cause leads the effect, and ( 3 ) the association between the cause and effect is statistically significant. Econometrically, it is nearly impossible to meet the first condition. The Granger-causality method addresses 


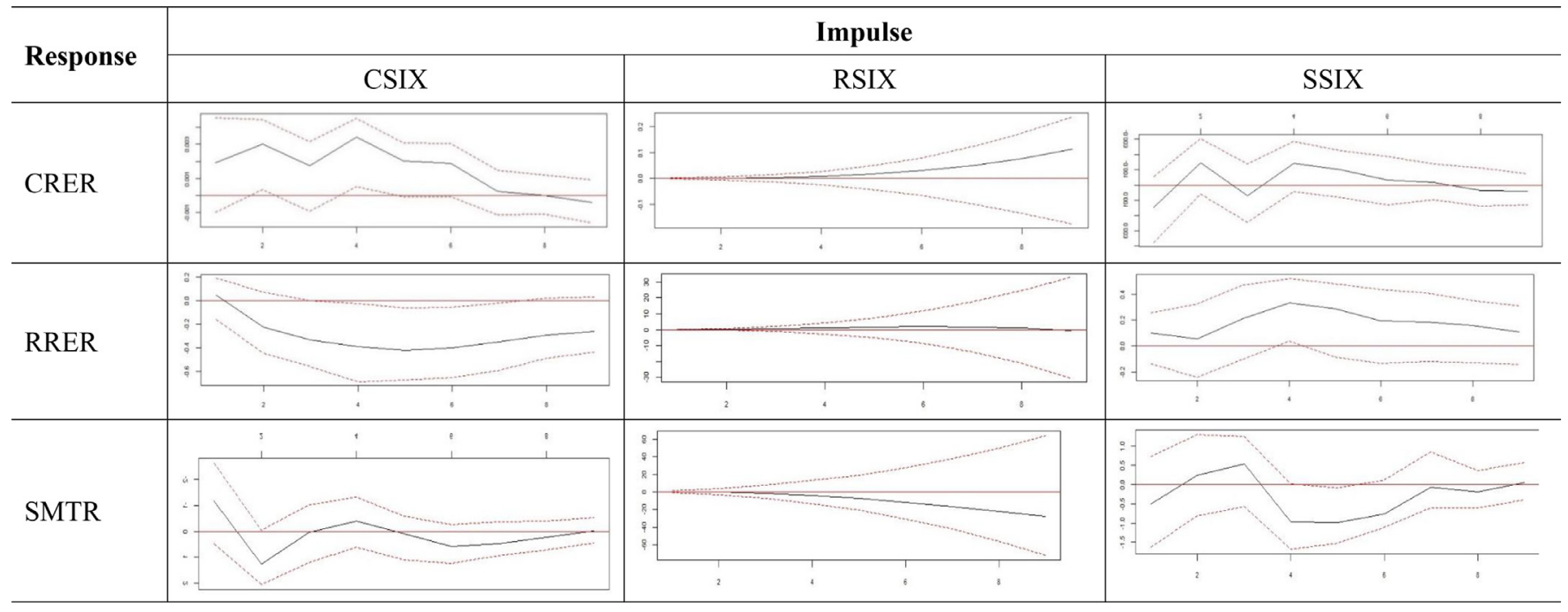

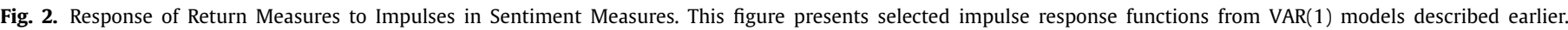

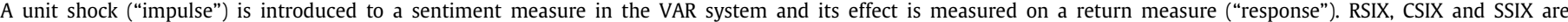

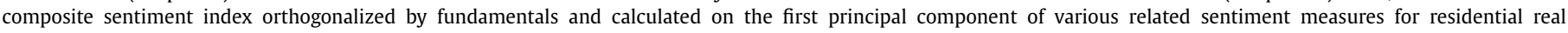

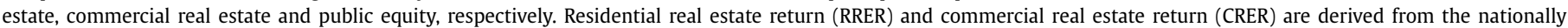

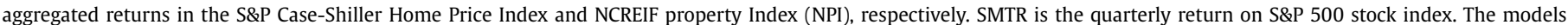

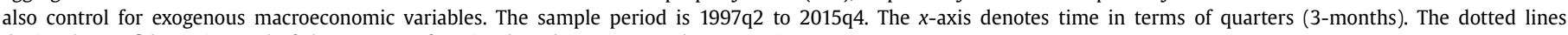
depict the confidence interval of the response function based on 100 runs bootstrapping.

the remaining two conditions. Therefore, results of Granger causality need to be interpreted with care, as the results may be prone to omitted variable bias.

\subsection{Impulse response function (IRF)}

Next, the IRFs describe the relationship between variables in the VAR system by introducing a hypothetical shock to an endogenous variable and comparing the response in other endogenous variables to the baseline process without a shock. Because of their endogenous nature, a shock will impact the variables directly as well as through transmission via the other variables in the system. We set this path to eight periods ahead (i.e., two years), since most effects diminish by this point, providing a comprehensive account of the reactions. We use orthogonal IRFs based on Cholesky decomposition, because of the assumption that the immediate shock is introduced only to the first variable (i.e., shock in different variables are independent) and error terms are in general contemporaneously correlated. Fig. 2 traces the time series path of each return variable after the shock of one standard deviation in the sentiment variables summarizing the corresponding cumulative effect across the following eight quarters. The IRFs are considered statistically significant if both the confidence intervals lie on the same side of the $X$-axis.

A shock to commercial real estate sentiment (impulse from CSIX) leads to significant responses from commercial (CRER) and residential (RRER) returns for up to 4 and 5 quarters respectively, whereas the public equity (SMTR) market remains unaffected over the quarters. On the other hand, a shock to the public market sentiment (SSIX) leads to significant responses from the residential (RRER) and stock market returns (SMTR), which persist for 4 to 5 quarters, respectively. Note again that CSIX derived from principal components of fundamentals-orthogonalized sentiment measures represents negative sentiment. Thus, the persistent response of CRER to CSIX implies a four-quarter contrarian view in commercial returns against commercial sentiment. This reflects the selfdisciplining behavior of commercial investors, who take a more careful stance when faced with irrational exuberance (and vice versa). On the contrary, residential returns exhibit a similar persistence, but in an opposite direction to commercial returns. Thus, a unit shock to commercial sentiment leads to a persistently significant response in residential returns, although on a higher significance level than what the sentiment would suggest. The third IRF in Panel $C$ shows that a unit shock to stock market sentiment leads to a much longer (eight quarters) significant response in residential real estate returns. Our IRF analyses suggest that all the three market segments are irrationally impacted by sentiments.

In short, we find that over a longer run residential returns are unduly inflated by irrational sentiments in both commercial real estate (CSIX) and public equity (SSIX) sectors, whereas commercial real estate return (CRER) is not affected by any sentiments. Stock market (SMTR) returns take a contrarian view to their own (SSIX) and commercial real estate sentiment measures (CSIX), although the evidence of the significant effect of CSIX on SMTR returns is not robust across model specifications between $\operatorname{VAR}(1)$ and VAR(3) in the Internet Appendix. The residential market sentiment does not play any significant role in determining returns across the three sectors studied. While Granger-causality provides information about in-sample fitting, it tells nothing about out-of-sample forecasting performance, which we address in the next sub-section.

\subsection{Forecasting power of sentiment}

In this sub-section, we compare the forecasting power of sentiment for commercial and residential real estate returns. Such a comparison is useful for "stress-testing" the previous findings. First, the data is split into training data (1995q3 to 2012q3) and testing data (2012q4 to 2015q3). Second, we compute the coefficients of the previously defined $\operatorname{VAR}(3)$ model for both the commercial and residential real estate market based on the training period data due to its superior explanatory power compared to $\operatorname{VAR}(1)$. Once the regression coefficients were estimated with and without the respective sentiment index, we predict one-step ahead returns for the testing period. Finally, we compare the forecasting errors between the two models for each quarter in the testing period. Since the forecasts are heavily dependent on the selected 
Table 5

Accuracy of return forecasts.

\begin{tabular}{lllll}
\hline Market & Measure & Forecast without Sentiment & Forecast with Sentiment & Improvement (w/o - with Sentiment) \\
\hline Commercial Real & RMSE & 1.171 & 1.155 & 0.016 \\
Estate (CRER) & MAE & 0.937 & 0.879 & 0.058 \\
Residential Real & RMSE & 0.570 & 0.675 & -0.105 \\
Estate (RRER) & MAE & 0.474 & 0.594 & -0.120 \\
Stock Market (SMTR) & RMSE & 1.168 & 1.084 & 0.084 \\
& MAE & 1.093 & 0.981 & 0.112 \\
\hline
\end{tabular}

This table provides forecasting comparisons based on VAR(3) models presented earlier. The models include three endogenous sentiment indices. RSIX, CSIX, and SSIX are composite sentiment indices orthogonalized by fundamentals and calculated on the first principal component of various related sentiment measures for residential real estate, commercial real estate, and public equity, respectively. Residential real estate return (RRER) and commercial real estate return (CRER) are derived from the nationally aggregated returns in the S\&P CaseShiller Home Price Index and NCREIF property Index (NPI), respectively. SMTR is the quarterly return on S\&P 500 stock index. The models also control for exogenous macroeconomic variables. The sample period is 1997q2 to 2015q4. RMSE and MAE are the root-mean squared and mean absolute error, respectively.

training period, we repeat the process for different testing periods ranging from 4 to 20 quarters. The results presented in Table 5 are average estimates over the different training periods. By using the Mean Absolute Error (MAE) and Root Mean Square Error (RMSE), we evaluate the forecasting accuracy of our market sentiment measures. ${ }^{22}$

Table 5 reflects two main findings: First, Commercial (CRER) and stock (SMTR) return predictions are superior when sentiment measures are included in the model. Sentiments reduce forecast errors both in terms of RMSE and MAE. More precisely, the inclusion of the three sentiment proxies in the VAR framework reduces the forecast error by 8 to 11 bps per quarter in SMTR and 2 to 6 bps per quarter in CRER. Second, residential return (RRER) models are better off without the sentiment measures, i.e. adding sentiments as additional variables leads to higher forecasting errors (by 1012 bps) per quarter.

If we consider a 10-year (40 quarters) holding period for CRE, the cumulative accuracy in return forecasts for CRE (SMTR) would be 80 bps to 240 bps ( 320 to $440 \mathrm{bps}$ ). If sentiments lead to disposition in an asset after a ten-year holding period, a 320 to 440 bps from the forecast accuracy may be sufficient in stock markets but economically insufficient in most CRE transactions. ${ }^{23}$ Therefore, although sentiments may be statistically significant in explaining commercial returns, the economic benefit of including sentiments in forecasting would depend on the transaction costs associated with the geographic market. Nevertheless, our study affirms the cross-over and direct role of sentiments in returns across residential, commercial real estate and stock markets.

\section{Conclusion}

While most asset pricing studies based on investor sentiments focus on stock markets, research investigating sentiment in private real estate markets is scarce. These markets are more likely to be characterized by imperfections, such as noisy traders, illiquidity, information asymmetries, and limits-to-arbitrage, and thus, are more prone to sentiments. Although residential real estate markets are known to play a significant role in economic cycles, there is limited knowledge on how commercial and residential real estate sectors are inter-connected and related to the general stock market through return, and in particularly, sentiment channels. Barring some exceptions (Ling and Naranjo, 1999; Duca and Ling, 2020), which consolidate real estate and capital markets within a single study, most studies examine residential

\footnotetext{
22 Hyndman and Koehler (2006) proposed to add the RMSE because the MAE underestimates the impact of large but infrequent errors.

${ }^{23}$ Anecdotal evidence suggests that the transaction costs are in the range of 3-5\% or more.
}

and commercial real estate, and equity markets in isolation. Moreover, Duca and Ling (2020) focus on direct spillover of returns across these markets rather than examining the role of cross-over effects in sentiments. Our study contributes to the literature by not only investigating how sentiment affects the private residential and commercial real estate market separately, but also treating them as one system with potential interdependence between their sentiment and return measures, as well as with investors' sentiment in stock markets. We detect a complex and nuanced association across public equity, residential real estate, and commercial real estate markets in terms of return and sentiment spillovers. Yet, the spillover in sentiments is not congruent with the spillover in returns across the three markets.

In the short run ( 1 to 3 quarters), sentiments in all markets are self-reinforcing. Although there is a significant cross-over of sentiments between residential and stock markets, commercial real estate sentiments evolve independently of the residential or public equity market sentiments. Our empirical results suggest that residential sentiments are unjustifiably exacerbated by both commercial and public equity market sentiments and there is weak evidence of residential sentiments influencing public equity sentiments. In contrast, the cross-over in returns presents a different story. Unlike sentiments, residential returns do not swell out of proportion as a result of rising commercial real estate returns, but rather take a contrarian view on commercial real estate returns. Barring some weak evidence, returns in the other two markets are broadly unaffected by sentiment measures (commercial real estate), or take a contrarian view to sentiments (stocks).

The findings highlight the role of commercial real estate markets, both in terms of sentiments and returns, played in a broader economic system. Although comparatively smaller than the residential sector, sentiments and returns in the commercial real estate sector have a significant impact on the economy over shorter and longer time horizons. More importantly, while the information content of residential sentiments is trivial, commercial sentiments and returns not only evolve independently, they also have significant effects on future returns in residential and public equity markets. Besides, incorporating commercial sentiments into return forecasting and eventually in transaction decisions may, in some cases, also prove to be economically reasonable.

Our study is not without its limitations. Survey- and financial ratio-based sentiment measures are biased and backward looking, respectively (Füss et al., 2019 and Ling et al., 2014). Furthermore, future studies could focus on explaining the asymmetric spillovers in sentiments across markets, which do not conform to the spillovers in returns. Finally, real estate markets are regional markets, which might require a more granular analysis at local levels. 


\section{Supplementary materials}

Supplementary material associated with this article can be found, in the online version, at doi:10.1016/j.jbankfin.2020.105799.

\section{CRediT authorship contribution statement}

Prashant Das: Data curation, Methodology, Investigation, Formal analysis, Writing - original draft, Writing - review \& editing. Roland Füss: Conceptualization, Methodology, Investigation, Formal analysis, Writing - original draft, Writing - review \& editing. Benjamin Hanle: Data curation, Methodology, Investigation, Formal analysis, Writing - review \& editing, Visualization. Isabel Nina Russ: Conceptualization, Data curation, Methodology, Investigation, Formal analysis, Writing - original draft.

\section{References}

Audrino, F., Tetereva, A., 2019. Sentiment spillover effects for US and European companies. J. Bank. Finance 106, 542-567.

Bai, J., Perron, P., 2003. Computation and analysis of multiple structural change models. J. Appl. Econom. 18 (1), 1-22.

Baker, M., Wurgler, J., 2006. Investor sentiment and the cross-section of stock returns. J. Finance 61 (4), 1645-1680.

Baker, M., Wurgler, J., 2007. Investor sentiment in the stock market. J. Econ. Perspect. 21 (2), 129-152.

Ball, M., Lizieri, C., MacGregor, B.D., 2002. The Economics of Commercial Property Markets. Routledge, London.

Bekaert, C., Ehrmann, M., Fratzscher, M., Mehl, A., 2014. The global crisis and equity market contagion. J. Finance 69 (6), 2597-2649.

Black, F., 1986. Noise. J. Finance 41 (3), 529-543.

Bokhari, S., Geltner, D., 2011. Loss aversion and anchoring in commercial real estate pricing: empirical evidence and price index implications. Real Estate Econ. 39 (4), 635-670.

Brown, G.W., Cliff, M.T., 2004. Investor sentiment and the near-term stock market. J. Empir. Finance 11 (1), 1-27.

Brown, G.W., Cliff, M.T., 2005. Investor sentiment and asset valuation. J. Bus. 78 (2), 405-440.

Campbell, J.Y., Grossman, S.J., Wang, J., 1993. Trading volume and serial correlation in stock returns. Q. J. Econ. 108 (4), 905-939.

Case, K.E., Shiller, R.J., 1988. The behavior of home buyers in boom and post-boom markets. N. Engl. Econ. Rev. 29-46 (November).

Charles, S.L., 2019. The financialization of single-family rental housing: an examination of real estate investment trusts' ownership of single-family houses in the Atlanta metropolitan area. J. Urban Aff. doi:10.1080/07352166.2019.1662728.

Chilton, K., Silverman, R.M., Chaudhry, R., Wang, C., 2018. The impact of single-family rental REITs on regional housing markets: a case study of Nashville, TN. Societies 8 (93).

Clarke, R.G., Statman, M., 1998. Bullish or bearish. Financ. Anal. J. 54 (3), 63-72.

Cotter, J., Stuart, G., Roll, R., 2018. Nowhere to run, nowhere to hide: asset diversification in a flat world.

Da, Z., Engelberg, J., Gao, P., 2015. The sum of all FEARS investor sentiment and asset prices. Rev. Financ. Stud. 28 (1), 1-32.

Das, P., Freybote, J., Marcato, G., 2015. An investigation into sentiment-induced institutional trading behavior and asset pricing in the REIT market. J. Real Estate Finance Econ. 51 (2), 160-189.

Das, P., Smith, P., Gallimore, P., 2017. Pricing extreme attributes in commercial real estate: the case of hotel transactions. J. Real Estate Finance Econ. 55 (3), $297-313$.

Duca, J.V., Ling, D.C., 2020. The other (commercial) real estate boom and bust: the effects of risk premia and regulatory capital arbitrage. In Challenges to global financial stability: interconnections,credit risk, business cycle and the role of market participants, Journal of Banking and Finance 112. doi:10.1016/j.jbankfin. 2018.03.006, March.

Evans, R.D., 1990. A transfer function analysis of real estate capitalization rates. J. Real Estate Res. 5 (3), 371-379.

Fama, E.F., 1991. Efficient capital markets: ii. J. Finance 46 (5), 1575-1617.

Fisher, K.L., Statman, M., 2000. Investor sentiment and stock returns. Financ. Anal. J. 56 (2), 16-23.

Freybote, J., Seagraves, P.A., 2018. Heterogeneous investor sentiment and institutional real estate investments. Real Estate Econ. 45 (1), 154-176.
Füss, R., Guidolin, M., Koeppel, C., 2019. Sentiment Risk Premia in the Cross-Section of Global Equity and Currency Returns (No. 19116). BAFFI CAREFIN, Centre for Applied Research on International Markets Banking Finance and Regulation, Universita'Bocconi.

Gau, G.W., 1987. Efficient real estate markets: paradox or paradigm? Real Estate Econ. 15 (2), 1-12.

Goodfellow, C., Bohl, M.T., Gebka, B., 2009. Together we invest? Individual and institutional investors' trading behaviour in Poland. Int. Rev. Financ. Anal. 18 (4), 212-221.

Grinblatt, M., Keloharju, M., 2000. The investment behavior and performance of various investor types : a study of Finland's unique data set. J. Financ. Econ. 55 (1), 43-67.

Hamilton, B.W., Schwab, R.M., 1985. Expected appreciation in urban housing markets. J. Urban Econ. 18 (1), 103-118.

Hoesli, M., Reka, K., 2015. Contagion channels between real estate and financial markets. Real Estate Econ. 43 (1), 101-138.

Hyndman, R.J., Koehler, A.B., 2006. Another look at measures of forecast accuracy. Int. J. Forecast 22 (4), 679-688.

Immergluck, D., Law, J., 2014. Investing in crisis: the methods, strategies, and expectations of investors in single-family foreclosed homes in distressed neighborhoods. Hous. Policy Debate 24 (3), 568-593.

Ioannides, Y.M., Rosenthal, S.S., 1994. Estimating the consumption and investment demands for housing and their effect on housing tenure status. Rev. Econ. Stat 76 (1), 127-141.

Kan, K., Kwong, S.K.S., Leung, C.K.Y., 2004. The dynamics and volatility of commercial and residential property prices: theory and evidence. J. Reg. Sci. 44 (1), 95-123.

Kumar, A., Lee, C., 2006. Retail investor sentiment and return comovements. J. Finance 61 (5), 2451-2486.

Lai, R.N., Order, R., 2017. U.S. house prices over the last 30 years: bubbles, regime shifts and market (In)Efficiency. Real Estate Econ. 45, 259-300.

Le, T., Ling, D., Ooi, J., 2015. Explaining house price dynamics: isolating the role of non-fundamentals. J. Money Credit Bank. 47 (1), 87-125.

Leamer, E.E., 2015. Housing really is the business cycle: what survives the lessons of 2008-09. J. Money Credit Bank. 47 (1), 43-50.

Lee, C.M.C., Shleifer, A., Thaler, R.H., 1991. Investor sentiment and the closed-end fund puzzle. J. Finance 46 (1), 75-109.

Levitt, S.D., Syverson, C., 2008. Market distortions when agents are better informed: the value of information in real estate transactions. Rev. Econ. Stat. 90 (4) 599-611.

Levitin, A.J., Wachter, S.M., 2013. The commercial real estate bubble. Harvard Bus. Law Rev. 3, 83.

Li, W., Rhee, G., Wang, S.S., 2017. Differences in herding: individual vs. institutional investors in China. Institutional Investors in China (SSRN: February 13, 2009).

Lilian, F.N., Wu, 2007. The trading behavior of institutions and individuals in Chinese equity markets. J. Bank. Finance 31 (9), 2695-2710.

Ling, D.C., Naranjo, A., 1999. The integration of commercial real estate markets and stock markets. Real Estate Econ. 27 (3), 483-515.

Ling, D.C., Naranjo, A., Scheick, B., 2014. Investor sentiment, limits to arbitrage and private market returns. Real Estate Econ. 42 (3), 531-577.

Lizieri, C., Baum, A., Scott, P., 2000. Ownership, occupation and risk: a view of the city of London office market. Urban Stud. 37 (7), 1109-1129.

Lowry, M., 2003. Why does IPO volume fluctuate so much? J. Financ. Econ. 67 (1), 3-40.

Malkiel, B.G., Fama, E.F., 1970. Efficient capital markets: a review of theory and empirical work. J. Finance 25 (2), 383-417.

McIntosh, W., Henderson, G.V., 1989. Efficiency of the office properties market. J. Real Estate Finance. Econ. 2 (1), 61-70.

Neal, R., Wheatley, S.M., 1998. Do measures of investor sentiment predict returns? J. Financ. Quant. Anal. 33 (4), 523-547.

Nofsinger, J.R., Sias, R.W., 1999. Herding and feedback trading by institutional and individual investors. J. Finance 54 (6), 2263-2295.

Quigley, A., 1999. Real Estate Prices and Economic Cycles. International Real Estate Review 2 (1), 1-20. Retrieved from https://escholarship.org/uc/item/58c6v2kx.

Ramiah, V., Davidson, S., 2007. Information-adjusted noise model: Evidence of inefficiency on the Australian stock market. J. Behav. Financ. 8 (4), 209-224.

Schmeling, M., 2007. Institutional and individual sentiment : smart money and noise trader risk. Int. J. Forecast 23 (1), 127-145.

Shefrin, H., 2008. A Behavioral Approach to Asset Pricing, second ed Academic Press Advanced.

Shefrin, H., Statman, M., 1994. Behavioral capital asset pricing theory. J. Financ. Quant. Anal. 29 (3), 323-349.

Sivitanidou, R., Sivitanides, P., 1999. Office capitalization rates: real estate and capital market influences. J. Real Estate Finance Econ. 18 (3), 297-322.

Vissing-Jørgensen, A., Attanasio, O.P., 2003. Stock-market participation, intertemporal substitution, and risk-aversion. Am. Econ. Rev. 93 (2), 383-391.

Yu, J., Yuan, Y., 2011. Investor sentiment and the mean-variance relation. J. Financ Econ. 100 (2), 367-381. 